Zbornik Instituta za kriminološka

i sociološka istraživanja

2020 / Vol. XXXIX / 2-3 / 27-44

Pregledni naučni rad

Primljeno: 10. avgusta 2020. godine

Prihvaćeno: 28. septembar 2020. godine

DOI: $10.47152 /$ ziksi2020232

UDK: $342.738: 343.261-052$

$351.75: 621.397 .4$

\title{
VIDEO NADZOR, BEZBEDNOST I PRAVO NA PRIVATNOST U ZATVORIMA*
}

\author{
Ana Batrićević* \\ Ivana Stepanović ${ }^{*}$
}

\begin{abstract}
Kontinuirani tehnološki razvoj nameće nove izazove u pogledu zaštite privatnosti, budući da pametni uređaji $i$ mehanizmi nadzora omogućavaju stvaranje velikih baza podataka o ličnosti. Kako na javnim mestima $i$ u privatnim domovima, tako i u ustanovama za izvršenje krivičnih sankcija, video nadzor preti da ugrozi pravo na privatnost $i$ stoga mora biti detaljno regulisan, da bi se uspostavio $i$ održavao balans između privatnosti $i$ bezbednosti. Uprkos tome, video nadzor u Srbiji nije regulisan posebnim zakonom, što otvara brojna sporna pitanja, posebno u kontekstu zatvora, gde se odluka o konkretnom načinu primene ovih tehnologija donosi u okviru pojedinačne ustanove za izvršenje krivičnih sankcija. Cilj ovog rada je da analizira na koji način je pravo na privatnost osuđenih lica konceptualizovano u međunarodnom pravu, da skrene pažnju na opravdanost, prednosti $i$ nedostatke video nadzora u zatvorima, kao $i$ da podigne svest o problemima koji se mogu pojaviti u ovoj nedovoljno regulisanoj oblasti.
\end{abstract}

\footnotetext{
* Tekst je nastao kao rezultat rada na projektu „Kriminal u Srbiji: fenomenologija, rizici i mogućnost socijalne intervencije“ (broj 47011) finansiran od strane Ministarstva prosvete, nauke i tehnološkog razvoja Republike Srbije.

* Viši naučni saradnik u Institutu za kriminološka i sociološka istraživanja, Beograd. E-mail: a.batricevic@yahoo.com

* Naučni saradnik u Institutu za kriminološka i sociološka istraživanja, Beograd. E-mail: ivana.stepanovic@gmail.com
} 


\author{
Zbornik IKSI, 2-3/2020 - A. Batrićević, I. Stepanović \\ „Video nadzor, bezbednost i pravo na privatnost u zatvorima”, (str. 27-44)
}

\begin{abstract}
KLJUČNE REČI: video nadzor / pravo na privatnost / bezbednost / zatvori / ljudska prava
\end{abstract}

\begin{abstract}
UVOD
Život u zatvoru neminovno ograničava privatnost pojedinca, ostavljajući ga izloženog pogledima, kamerama i pretresima dok se njegovi lični podaci zavode $\mathrm{u}$ dosijea i DNK baze (Marshall, Thomas, 2017: 183). Iako relevantni međunarodni dokumenti nalažu poštovanje ljudskih prava osuđenih lica (više o tome: Batrićević, 2011: 135-156), uključujući i pravo na privatnost, u onoj meri u kojoj je to moguće u takvim ustanovama, ovo pitanje i dalje je sporno, kako u svetu tako i u Srbiji i ostavlja prostor za razmatranje ispravnosti i opravdanosti pojedinih zakonskih rešenja, kao i korektnosti primene video nadzora u praksi. Tome doprinosi i okolnost da zahtevi bezbednosti neretko dolaze u koliziju sa osnovnim principima ljudskih prava i potrebom da se u zatvorima obezbede uslovi života koji ne ugrožavaju ljudsko dostojanstvo. Navedeno se ne odnosi samo na nadzor osuđenih lica koja se nalaze na izdržavanju kazne zatvora, već i na druge oblike nadzora prestupnika, koji se sprovode izvan zatvorskih ustanova (Batrićević et al, 2020: 587605; Želeskov Đorić, Batrićević, 2014: 75-94; Želeskov Đorić, Batrićević, 2013).
\end{abstract}

Pojam prava na privatnost u zatvorima nije dovoljno jasno određen. Zahtev da se privatnost osuđenih lica poštuje koliko god je to moguće, kako se naglašava u relevantnim međunarodnim dokumentima analiziranim u posebnom delu ovog rada, ostavlja prostor različitim interpretacijama, pogotovo u državama u kojima postoji preopterećenost smeštajnih kapaciteta penitencijarnih ustanova, gde spada i Srbija (Dimovski, Kostić, 2015: 168; Grujić, Milić, 2016: 286), ali i SAD (Lugo and Wooldredge, 2017; MacDonald, 2018: 65). Odsustvo opšte prihvaćene definicije pojma privatnosti u zatvorima posledica je mnogo šireg problema konceptualizacije privatnosti, kako u teoriji tako i u pravnim izvorima. Reč je o pojmu koji nije u potpunosti definisan i omeđen (Bauman, 2010: 8; Glass, 2010: 59) i koji se posmatra kao subjektivan (Yu, 2016: 2752), pa je zbog toga problematičan i kada se posmatra u kontekstu zaštite svih vrsta digitalnih podataka. S obzirom na to da su digitalni mediji i digitalne tehnologije kreirane tako da sakupljaju privatne podatke, odnosno da beleže i prate ponašanje, interakcije i preferencije pojedinaca, oni su sami po sebi sistemi nadzora (Stepanović, 2019: 46), pa se u tom smislu postavlja i pitanje privatnosti informacija (Mai, 2020: 171).

Koncept prava na privatnost je suštinski ograničen interesom da se očuva bezbednost, jer se pravo na privatnost pojedincu može uskratiti upravo onda kada je to neophodno radi očuvanja bezbednosti. Bezbednost se, u tom smislu, pojavljuje kao jedan od ključnih faktora koji ograničavaju pravo na privatnost (Stepanović, 2018: 110) i to ne samo u kontekstu velikih baza podataka (Maple, 2017: 155), već i kada se pravo na privatnost posmatra u kontekstu zatvora i lica lišenih slobode, gde potreba za očuvanjem bezbednosti i sigurnosti neretko postaje prioritet u odnosu na dobrobit pojedinca. Nadzor se tako smatra preventivnom merom, koja podrazumeva 


\section{Zbornik IKSI, 2-3/2O2O - A. Batrićević, I. Stepanović \\ „Video nadzor, bezbednost i pravo na privatnost u zatvorima”, (str. 27-44)}

žrtvovanje privatnosti osuđenika kao individualne slobode zarad dobrobiti zatvorske zajednice (Stepanović, 2015: 82). Privatnost se u ustanovama za izvršenje krivičnih sankcija nalazi nisko na listi prioriteta, jer se radi o visoko kontrolisanim sredinama. U velikoj meri se podrazumeva da su sigurnost i bezbednost osuđenih lica, zatvorskog osoblja i cele ustanove prioritet, pa postoje ustaljene prakse gotovo rutinskog kršenja privatnosti i uznemiravanja zatvorenika u bilo koje doba dana ili noći (Jewkes, Crewe, Bennett, 2016: 126).

Debata oko sukoba između prava na privatnost i interesa bezbednosti u zatvorima deo je šire rasprave. Nakon terorističkih napada u Sjedinjenim Američkim Državama i Evropi 2001. godine, ideja o balansu između privatnosti i bezbednosti dovedena je u pitanje posredstvom argumenta "nemam šta da sakrijem" ("nothing to hide argument") i isticanjem da je neophodno odreći se značajnog dela privatnosti radi osiguranja bezbednosti u društvu (Stepanović, 2014: 171). Projekti masovnog nadzora, pogotovo projekat sprovođen od strane američke Nacionalne službe za bezbednost, koji je 2013. godine razotkrio Edvard Snouden (Snouden, 2020) predstavljaju ključne primere, koji pokazuju kako se bezbednosti daje prednost u odnosu na privatnost i to na štetu građana, čije je pravo na nepovredivost prepiske u tajnosti kršeno.

Jedan od primera iskorišćavanja "nothing to hide" argumenta za pooštravanje bezbednosnih mera u zatvorima predstavlja i pokušaj Velike Britanije da kreira takozvane javne politike „maksimalne bezbednosti“ (Drake, 2012: 33). Naime, pokazalo se da su represivni zatvorski režimi ponikli iz ideje o minimalizovanju koncepta blagostanja u javnim politikama u oblasti izvršenja krivičnih sankcija, te da je to dovelo do pomeranja fokusa sa dobrobiti pojedinca na dobrobit zajednice, koja bi trebalo da ima koristi od radikalnih bezbednosnih mera $\mathrm{u}$ zatvorima (Drake, 2012: 54).

Dakle, ideja da bi pojačane mere bezbednosti kojima se krši pravo pojedinca na privatnost mogle unaprediti dobrobit zajednice inicirala je mnoge projekte nadzora građana, ali i pooštravanje režima bezbednosti u zatvorima. Međutim, argumenti koji postavljaju bezbednost visoko na lestvici prioriteta često su kritikovani. Jedan od ključnih argumenata je da je čitava debata o tome kako uspostaviti odnos između privatnosti i bezbednosti lažna, pošto već sadrži argument o neophodnosti razmene ili žrtvovanja jednog interesa zarad drugog, ignorišući mogućnost njihove koegzistenicje (Solove, 2011: 2; Moore, 2011: 141; Waldron, 2010: 10). Ideja o davanju prioriteta bezbednosti kritikovana je i iz ugla odbrane klasičnog liberalizma, zasnovanog na idejama odbrane prava i sloboda, nasuprot modernom liberalizmu, koji preokreće paradigmu i podređuje ljudska prava i slobode konceptu bezbednosti (Pavone et al., 2016: 225). Jedna od suštinskih zamerki odnosi se i na neodređenost samog pojma bezbednosti, koji nije dovoljno definisan da bi se moglo govoriti o žrtvovanju privatnosti u korist bezbednosti (Waldron, 2010: 12). Iz navedenog proizlazi i ključna dilema - kako ispoštovati pravo osuđenih lica na privatnost, sa jedne strane, a istovremeno osigurati njihovu bezbednost $\mathrm{i}$ bezbednost $\mathrm{u}$ zatvoru uopšte, odnosno, kako uspostaviti balans između ova dva interesa. 


\author{
Zbornik IKSI, 2-3/2020 - A. Batrićević, I. Stepanović \\ „Video nadzor, bezbednost i pravo na privatnost u zatvorima”, (str. 27-44)
}

\title{
1. RAZVOJ VIDEO NADZORA U ZATVORIMA
}

Sa upotrebom složenih sistema video nadzora u cilju zaštite privatnog i javnog prostora otpočinje se krajem šezdesetih godina dvadesetog veka u bankama i prodavnicama širom SAD i Velike Britanije, da bi se video nadzor postepeno proširio na druge objekte i stekao status važnog metoda prevencije kriminaliteta (Fajf, Banister, 2002, prema: Kovačević-Lepojević, Žunić-Pavlović, 2012: 327). Složeni sistemi video nadzora uvode se u američke i australijske ustanove za izvršenje krivičnih sankcija već sedamdesetih godina 20. veka, a danas su prisutni u skoro svim ustanovama ovog tipa u svetu (Kovačević-Lepojević, Žunić-Pavlović, 2012: 335).

U većini modernih zatvora postoji centralna jedinica iz koje se sprovodi video nadzor i putem radio veze vrši kontrola nad otvaranjem i zatvaranjem fizičkih barijera i koja je po pravilu ili fizički izdvojena iz zatvora ili obezbeđena posebnim merama, budući da se iz nje upravlja kompletnom ustanovom (Fairweather, McConville, 2013, prema: Džunić, Dragojlović, 2019: 202). Usled dotrajalosti i nedostatka sredstava za održavanje postojećih, već zastarelih sistema za video nadzor, sve veći broj ustanova za izvršenje krivičnih sankcija u svetu zamenjuje svoje stare analogne sisteme novim, bilo hibridnim bilo u potpunosti digitalizovanim sistemima, koji omogućavaju: veću pokrivenost, jasnije snimke, praćenje pojedinačnih osuđenika, brzu pretragu arhiviranih video snimaka, aktiviranje alarma u slučaju pojave određenih nepoželjnih aktivnosti, prepoznavanje lica, postavljanje uređaja za nadzor i u unutrašnje i na spoljašnje delove ustanove, poput dvorišta i sportskih terena, uz mogućnost detektovanja pokreta u određenim prostorima tokom ustanovljenog vremenskog perioda, mogućnost pristupa video snimcima preko mobilnih telefona, kao i automatsko prilagođavanje veličine video snimka prilikom gledanja uživo, čime se značajno smanjuje opterećenje mreže i olakšava pregled preko mobilnih telefona (Henriquez, 2019).

Moderni nadzor, prema Fukou, funkcioniše po principu „panoptikona“, odnosno arhitektonske koncepcije zatvora koju je osmislio filozof Džeremi Bentam, koju čini zgrada okruglog oblika sa zatvorskim ćelijama na periferiji i nadzornim tornjem u centru. Zahvaljujući kompleksnom sistemu osvetljenja, posmatrač smešten u centru može da osmatra sve zatvorske ćelije, a da sam ne bude viđen. Pošto zatvorenici ne znaju u kom trenutku ih on posmatra, oni su prinuđeni da se neprekidno ponašaju kao da su pod nadzorom (Bentham, 1995: 43). Savremeni digitalni nadzor funkcioniše po principu panoptikona, jer kamere omogućavaju neprekidni nadzor, a nadzirani pojedinci nikada ne znaju kada ih neko posmatra. Ova preventivna funkcija panoptikona karakteristična je za sve savremene mehanizme nadzora, pa upravo zato Fuko koristi ovaj Bentamov izum kao metaforu, koja opisuje ne samo kako funkcioniše moderan zatvor, već i čitavo moderno društvo, čije su institucije moći ustrojene po principu nadzora od strane posmatrača koji sam nije vidljiv onima koji su predmet posmatranja (Foucault, 2020: 200). Bauman koristi istu metaforu da dočara kako nadzor sa pojavom savremenih informacionih tehnologija izlazi izvan granica institucija poput zatvora, škola, fabrika i bolnica, o kojima je govorio Fuko, pa tako panoptikon u obliku mobilinih telefona i laptop računara sa 


\author{
Zbornik IKSI, 2-3/2O2O - A. Batrićević, I. Stepanović \\ „Video nadzor, bezbednost i pravo na privatnost u zatvorima”, (str. 27-44)
}

integrisanim tehnologijama nadzora (Stepanović, 2020: 10) postaje neka vrsta „puževe kućice“, koju svako mora da nosi sa sobom (Bauman, Lyon, 2013: 54). U tom smislu, pojam panoptikona se danas vezuje za tehnološki progres, kompjuterizaciju, internet, sisteme video nadzora kao i veb kamere (Brunon-Ernst, Tusseau, 2012 :188).

\title{
2. CILJEVI I OPRAVDANOST VIDEO NADZORA U ZATVORIMA
}

Teorijski gledano, osnova za primenu video nadzora, uključujući i njegovu primenu u zatvorima, leži u takozvanoj situacionoj prevenciji kriminaliteta, koja se sastoji u nastojanju da se identifikuju, promene i kontrolišu faktori koji deluju u onim situacijama u kojima dolazi do kriminalnog ponašanja, a obuhvata tehnike koje otežavaju vršenje kriminalnih aktivnosti i koje doprinose da se kriminalitet predstavi kao opasniji, manje poželjan, manje opravdan i manje provokativan (KovačevićLepojević, Žunić-Pavlović, 2012: 327). Međutim ova preventivna funkcija direktno zavisi od povređivanja prava na privatnost, jer se sadržina video snimaka smatra vrstom podataka o ličnosti. Na taj način bezbednost postaje prioritet na račun slobode i privatnosti, pogotovo kada se uzmu u obzir mogućnosti zloupotrebe svojstvene takvim sistemima nadzora. Osim toga, privatnost podataka "zavisi od toga kome oni pripadaju", pa samim tim pitanje privatnosti u kontekstu video nadzora postaje pitanje svojine na tim podacima (Snouden, 2020: 208). Preventivna uloga nadzornih kamera problematična je kako u zatvorima tako i u svim drugim prostorima upravo zbog toga što one ugrožavaju privatnost ne samo onih koji su prekršili pravila ili učinili krivično delo, već i onih koji se ponašaju savesno i ne ugrožavaju bezbednost.

Paralelno sa proširivanjem ovlašćenja u pogledu zadiranja u svakodnevni život i privatnost osuđenih lica, ustanove za izvršenje krivičnih sankcija suočavaju se i sa nizom osobenih bezbednosnih izazova, uključujući: bekstva osuđenih lica, uzimanje talaca, nezakonite aktivnosti takozvanih zatvorskih bandi, krijumčarenje, pobune i preopterećenost smeštajnih kapaciteta (Henriquez, 2019). Potreba da se ovi specifični bezbednosni rizici ublaže čini primenu video nadzora u modernim zatvorima ne samo opravdanom već i neophodnom (Henriquez, 2019). Uz to, video nadzor se pokazao kao posebno koristan u slučaju manjka zatvorskog osoblja, budući da predstavlja adekvatnu zamenu za nadzor od strane ovih lica, čime se omogućava još detaljnije i sveobuhvatnije praćenje aktivnosti osuđenika (Henriquez, 2019).

Primarni cilj video nadzora $\mathrm{u}$ zatvorima jeste da se otkriju i spreče neželjena ponašanja specifična za ovu sredinu, poput samopovređivanja, samoubistava, bekstava, nasilja i distribucije i zloupotrebe psihoaktivnih supstanci (KovačevićLepojević, Žunić-Pavlović, 2012: 335). Osim toga, preovladava stav da primena video nadzora $\mathrm{u}$ zatvorima može doprineti koordinaciji prilikom donošenja odluka povodom pojedinačnih incidenata, kao i lakšem prikupljanju dokaza i unapređenju bezbednosti (Allard, Wortley, Stewart, 2006, prema: Kovačević-Lepojević, ŽunićPavlović, 2012: 335). Takođe, veruje se da video nadzor može sprečiti nasilje kako 


\section{Zbornik IKSI, 2-3/2O2O - A. Batrićević, I. Stepanović \\ „Video nadzor, bezbednost i pravo na privatnost u zatvorima”, (str. 27-44)}

među zatvorenicima, tako i između zatvorenika i zatvorskog osoblja (Gibbons, De B. Katzenbac, 2006: 34). Smatra se da video nadzor može doprineti prevenciji kriminaliteta tako što omogućava: otkrivanje učinioca već tokom vršenja krivičnog dela ili neposredno posle toga, smanjenje vremena tokom kojeg se može učiniti krivično delo, intenziviranje prirodnog nadzora, unapređenje efikasnosti fizičkog obezbeđenja, jačanje socijalne kohezije, povećanje opreznosti, pojačavanje osećanja straha od javne sramote, podsticanje kretanja u oblastima koje su pokrivene video nadzorom i porast broja prijava krivičnih dela policiji (Kovačević-Lepojević, ŽunićPavlović, 2012:327).

Visok stepen poverenja u domašaje video nadzora kao sredstva za prevenciju nasilja $\mathrm{u}$ zatvorima potvrđuje i nagodba postignuta 2006. godine ${ }^{1}$ povodom većeg broja pritužbi zatvorenika protiv zaposlenih $\mathrm{u}$ zatvorima $\mathrm{u}$ državi Njujork zbog prekomerne upotrebe sile, a posebno zbog prekoračenja ovlašćenja prilikom upotrebe palica (Gibbons, De B. Katzenbac, 2006: 34; Boston, 2006: 155-158). Naime, ključni deo ove nagodbe bio je upravo uspostavljanje obaveze da se na zidove unutar pomenutih ustanova za izvršenje krivičnih sankcija instaliraju stotine novih video kamera, kao dodatak već postojećem broju istih (koji je premašivao dve hiljade), kako bi se video nadzorom pokrile što veće površine unutar zatvorskih kompleksa (Gibbons, De B. Katzenbac, 2006: 34).

Sve šira primena video nadzora u ustanovama za izvršenje krivičnih sankcija propraćena sve većim ulaganjima u njegovo tehničko usavršavanje ipak ne počiva na čvrstim empirijskim dokazima o njegovoj efikasnosti (Kovačević-Lepojević, ŽunićPavlović, 2012: 335). Na primer, Kilburnov eksperiment, koji je imao za cilj da ispita percepciju promena (od strane zaposlenih i pritvorenika) nakon uvođenja video nadzora, pokazao je da su zaposleni smatrali da video nadzor, uprkos određenim korisnim stranama, nije doprineo unapređenju bezbednosti, dok su pritvorenici smatrali da im je bezbednost ipak unapređena, da bi se obe grupe složile oko toga da je uvođenjem video nadzora svima ugrožena privatnost (Kovačević-Lepojević, ŽunićPavlović, 2012: 336).

Dosadašnja iskustva potvrdila su da video nadzor, kao dodatni način da se osigura bezbednost u zatvorima, ima određene pozitivne strane (Allard, Wortley, Stewart, 2006; Henriquez, 2019). Međutim, praksa isto tako pokazuje da njegovo uvođenje, ali i njegovo odsustvo na pojedinim mestima, otvara prostor za različite zloupotrebe. Sa jedne strane, mnogi međunarodni dokumenti, čije su odredbe analizirane $u$ posebnom delu ovog rada, direktno ili indirektno postavljaju ograničenja u pogledu primene video nadzora u ustanovama za izvršenje krivičnih sankcija sa ciljem zaštite dostojanstva ličnosti, odnosno prava na privatnost. Sa druge strane, upravo ta ograničenja omogućavaju različite nepravilnosti i zloupotrebe (Džunić, Dragojlović, 2019: 203). Naime, primena video nadzora, kao mere foormalnog nadzora $u$ savremenim zavodskim ustanovama može povezati i sa neformalnim sistemom života osuđenih lica (Joković, 2018: 311). U domaćim zatvorima nadzorne kamere po

1 Videti: Ingles v. Toro, 438 F. Supp. $2 d$ 203 (S.D.N.Y.) (2006), dostupno na: https://www.clearinghouse.net/detail.php?id=5483, stranici pristupljeno 02.07.2020. 


\section{Zbormik IKSI, 2-3/2020 - A. Batrićević, I. Stepanović \\ „Video nadzor, bezbednost i pravo na privatnost u zatvorima”, (str. 27-44)}

pravilu postoje u zajedničkim prostorijama ili hodnicima, ali nisu instalirane $\mathrm{u}$ spavaonicama i toaletima, što je svakako u skladu sa međunarodnim standardima zaštite privatnosti (Džunić, Dragojlović, 2019: 203; uorediti sa: Allard et al., 2008). Međutim, smeštajni kapaciteti ustanova za izvršenje krivičnih sankcija mahom su preopterećeni ${ }^{2}$, pa neretko i po nekoliko desetina ljudi spava u istoj prostoriji $3 i z$ čega sledi da nepokrivenosti ovih prostorija video nadzorom može predstavljati bezbednosni rizik. Dosadašnja praksa pokazuje da se različiti fizički sukobi i zlostavljanja načešće dešavaju upravo u zatvorskim toaletima i prostoru za kupanje, te da snažan pritisak neformalnog sistema i strah od odmazde dovode do toga da žrtve kao uzroke svojih povreda po pravilu navode klizave površine toaleta i udarac o pod (Džunić, Dragojlović, 2019: 203). Imajući to u vidu, trebalo bi pored uticaja video nadzora na ponašanje osuđenika uzimati u obzir i arhitektonska rešenja koja su u ustanovama zastupljena, kao i druge faktore poput karakteristika pripadnika obezbeđenja, tipa prostorija u kojima osuđenici borave itd (Morris, Worrall, 2010: 21).

\section{VIDEO NADZOR I PRAVO OSUĐENIH LICA NA PRIVATNOST U MEĐUNARODNIM DOKUMENTIMA}

Veza između pojmova video nadzora, bezbednosti i kontrole postoji od samog početka korišćenja ovih tehnologija, a u dvadesetom i dvadeset i prvom veku prakse nadzora se intenzivno povezuju sa konceptom privatnosti, zato što se informacije prikupljene primenom video nadzora smatraju podacima o ličnosti, što implicira da se i na podatke o ličnosti prikupljene na taj način primenjuju opšti standardi o zaštiti podataka o ličnosti postavljeni relevantnim međunarodnim pravnim izvorima. $4 \mathrm{Na}$ ovom mestu treba naglasiti da je u međunarodnom pravu, pojam video nadzora definisan u odredbama Uputstava 3/2019 o obradi podataka o ličnosti prikupljenih putem video nadzora (European Data Protection Board, 2019). Iako se odnose na primenu video nadzora u svakodnevnom životu, a ne u kontekstu očuvanja bezbednosti u ustanovama izvršenja krivičnih sankcija (gde se primenjuju posebna pravila), one se mogu shodno primeniti i u tom kontekstu, barem kada je u pitanju definisanje pojma video nadzora. Prema ovim Uputstvima, video nadzor podrazumeva sistematsko automatsko nadziranje određenog prostora pomoću optičkih ili audio-vizuelnih sredstava, najčešce u svrhu zaštite imovine, odnosno

\footnotetext{
2 Više o tome: Strategija za smanjenje preopterećenosti smeštajnih kapaciteta u zavodima za izvršenje krivičnih sankcija u Republici Srbiji do 2020. godine, Službeni glasnik RS, br. 43/2017.

3 Premda je, prema navodima Uprave za izvršenje krivičnih sankcija Ministarstva pravde Republike Srbije u poslednjih par godina došlo do smanjenja stope prenaseljenosti ustanova za izvršenje krivičnih sankcija kao rezultat intenzivnih napora da se poboljšaju uslovi u kojima žive lica lišena slobode u našoj zemlji, dostupno na: https://www.paragraf.rs/dnevne-vesti/240620/240620-vest6.html, stranici pristupljeno 06.07.2020. Više o negativnim posledicama prenaseljenosti ustanova za izvršenje krivičnih sankcija, posebno u odnosu na zdravlje osuđenih lica: Batrićević, Ilijić, 2014: 441 - 450.

4 Videti: European Data Protection Supervisor, Video-surveillance, dostupno na: https://edps.europa.eu/data-protection/data-protection/reference-library/video-surveillance en, stranici pristupljeno 03.07.2020.
} 


\author{
Zbormik IKSI, 2-3/202O - A. Batrićević, I. Stepanović \\ „Video nadzor, bezbednost i pravo na privatnost u zatvorima”, (str. 27-44)
}

života i zdravlja pojedinca, koje podrazumeva prikupljanje i čuvanje slikovnih ili audio-vizuelnih informacija o svim osobama koje stupe u nadzirani prostor i koje se mogu identifikovati na osnovu izgleda ili drugih specifičnih elemenata (European Data Protection Board, 2019: 7).

Prilikom analiziranja međunarodnih standarda od značaja za zaštitu prava na privatnost uopšte, a posebno u kontekstu video nadzora u zatvorima, treba imati u vidu da pravo na privatnost obuhvata nekoliko na prvi pogled raznorodnih ljudskih prava, uključujući pravo na poštovanje: privatnog života, porodičnog života, nepovredivosti doma i prepiske, kao i časti i ugleda pojedinca (Paunović, Krivokapić, Krstić, 2013: 179). Ova ljudska prava zajemčena su brojnim međunarodnim pravnim izvorima, kako univerzalnog tako i regionalnog polja primene.

Od međunarodnih pravnih izvora univerzalnog karaktera kao najrelevantniji za zaštitu prava na privatnost se izdvajaju: 1) Univerzalna deklaracija o ljudskim pravima $^{5}$ i 2) Međunarodni pakt o građanskim i političkim pravima ${ }^{6}$. Na evropskom nivou, za zaštitu prava na privatnost najznačajnije su odredbe: 1) Evropske konvencije za zaštitu ljudskih prava i osnovnih sloboda7 i 2) Konvencije o zaštiti lica u odnosu na automatsku obradu ličnih podataka ${ }^{8}$ i Protokola uz tu Konvenciju9. U državama članicama Evropske unije zaštitu podataka o ličnosti uređuje Uredba (EU) 2016/679 o zaštiti fizičkih lica u odnosu na obradu podataka o ličnosti, i o slobodnom kretanju takvih podataka i o stavljanju Direktive 95/46/EZ van snage (Opšta uredba o zaštiti podataka) ${ }^{10}$. Međutim, ona se ne primenjuje na obradu podataka o ličnosti koju vrše nadležni organi u svrhu: sprečavanja, istrage ili otkrivanja krivičnih dela, izvršenja krivičnih sankcija, kao i u svrhu zaštite od ili sprečavanja pretnji za javnu bezbednost (član 2. stav 2. tačka g Opšte uredbe o zaštiti podataka), već je ta oblast regulisana Direktivom (EU) 2016/680 Evropskog

\footnotetext{
5 UN General Assembly, Universal Declaration of Human Rights, 10 December 1948, 217 A (III), https://www.refworld.org/docid/3ae6b3712c.html, 22.06.2020.

${ }_{6}^{6}$ Zakon o ratifikaciji Međunarodnog pakta o građanskim i političkim pravima, Službeni list SFRJ, br. 7/1971-73.

7 Zakon o ratifikaciji Evropske konvencije za zaštitu ljudskih prava i osnovnih sloboda, izmenjene u skladu sa Protokolom br. 11, Protokola uz Konvenciju za zaštitu ljudskih prava i osnovnih sloboda, Protokola br. 4 uz Konvenciju za zaštitu ljudskih prava i osnovnih sloboda kojim se obezbeđuju izvesna prava i slobode koji nisu uključeni u Konvenciju i prvi Protokol uz nju, Protokola br. 6 uz Konvenciju za zaštitu ljudskih prava i osnovnih sloboda o ukidanju smrtne kazne, Protokola br. 7 uz Konvenciju za zaštitu ljudskih prava i osnovnih sloboda, Protokola br. 12 uz Konvenciju za zaštitu ljudskih prava i osnovnih sloboda i Protokola br. 13 uz Konvenciju za zaštitu ljudskih prava i osnovnih sloboda o ukidanju smrtne kazne u svim okolnostima, Službeni list SCG - Međunarodni ugovori, br. 9/2003, 5/2005 i 7/2005 i Službeni glasnik RS - Međunarodni ugovori, br. 12/2010 i 10/2015.

8 Zakon o potvrđivanju Konvencije o zaštiti lica u odnosu na automatsku obradu ličnih podataka, Službeni list SRJ - Međunarodni ugovori, br. 1/1992, Službeni list SCG - Međunarodni ugovori, br. 11/2005 i Službeni glasnik RS - Međunarodni ugovori, br. 98/2008 i 12/2010.

9 Zakon o potvrđivanju Protokola o izmenama i dopunama Konvencije o zaštiti lica u odnosu na automatsku obradu ličnih podataka, Službeni glasnik RS - Međunarodni ugovori, br. 4/2020.

${ }^{10}$ Regulation (EU) 2016/679 of the European Parliament and of the Council of 27 April 2016 on the protection of natural persons with regard to the processing of personal data and on the free movement of such data, and repealing Directive 95/46/EC (General Data Protection Regulation), OJ L 119, 4.5.2016, p. 1-88, https://eur-lex.europa.eu/eli/reg/2016/679/oj , 22.06.2020.
} 


\section{Zbormik IKSI, 2-3/2020 - A. Batrićević, I. Stepanović \\ „Video nadzor, bezbednost i pravo na privatnost u zatvorima”, (str. 27-44)}

parlamenta i Saveta od 27. aprila 2016. o zaštiti pojedinaca u vezi sa obradom ličnih podataka od strane nadležnih organa u svrhe sprečavanja, istrage, otkrivanja ili krivičnog gonjenja učinilaca krivičnih dela ili izvršavanja krivičnih sankcija i o slobodnom kretanju takvih podataka i o stavljanju van snage Okvirne odluke Saveta 2008/977/JHA ${ }^{11}$ (Direktiva o zaštiti podataka o ličnosti u odnosu na policijske vlasti i u krivičnom postupku, poznata i kao Policijska direktiva). Konačno, u kontekstu zaštite prava na privatnost osuđenih lica na evropskom nivou, najveći značaj imaju odredbe Evropskih zatvorskih pravila ${ }^{12}$ kojima se garantuje poštovanje osnovnih ljudskih prava lica lišenih slobode a za problematiku video nadzora, relevantna je i Preporuka Komiteta ministara državama članicama o tretmanu od strane zatvorske administracije zatvorenika koji izdržavaju doživotne $i$ druge dugogodišnje kazne iz 20o3. godine ${ }^{13}$.

Univerzalna deklaracija o ljudskim pravima u članu 12. propisuje da: "Niko ne sme biti izložen proizvoljnom mešanju u svoju privatnost, porodicu, dom ili prepisku, niti napadima na čast ili ugled". Međunarodni pakt o građanskim i političkim pravima u stavu 1. člana 17. ističe da: "Niko ne može biti predmet samovoljnih ili nezakonitih mešanja u njegov privatni život, porodicu, stan, prepisku, niti nezakonitih povreda nanesenih njegovoj časti ili ugledu". U stavu 2. istog člana naglašeno je da: "Svako lice ima pravo na pravnu zaštitu protiv ovakvih mešanja ili povreda". Evropska konvencija za zaštitu ljudskih prava i osnovnih sloboda stavom 1. člana 8. predviđa da: "Svako ima pravo na poštovanje svog privatnog i porodičnog života, doma i prepiske", dok stavom 2. istog člana zabranjuje da se javne vlasti mešaju u vršenje tog prava, osim "ako to nije u skladu sa zakonom i neophodno u demokratskom društvu u interesu nacionalne bezbednosti, javne bezbednosti ili ekonomske dobrobiti zemlje, radi sprečavanja nereda ili kriminala, zaštite zdravlja ili morala, ili radi zaštite prava i sloboda drugih". Evropska konvencija u članu 8. ne spominje eksplicitno zaštitu časti i ugleda, nego govori samo o poštovanju prava na privatni i porodični život, dom i prepisku, ali zato Rezolucija broj 428. Parlamentarne skupštine Saveta Evrope iz 1970. godine ${ }^{14}$ utvrđuje da pravo na privatnost podrazumeva: 1) pravo da svako živi svoj život uz minimalno mešanje državnih vlasti

\footnotetext{
${ }_{11}$ Directive (EU) 2016/680 of the European Parliament and of the Council of 27 April 2016 on the protection of natural persons with regard to the processing of personal data by competent authorities for the purposes of the prevention, investigation, detection or prosecution of criminal offences or the execution of criminal penalties, and on the free movement of such data, and repealing Council Framework Decision 2008/977/JHA, https://eur-lex.europa.eu/legal-content/EN/TXT/PDF/?uri=CELEX:32016Lo680\&from $=\mathrm{EN}, 24.06 .2020$.

12 Council of Europe: Committee of Ministers, Recommendation Rec(2006)2 of the Committee of Ministers to Member States on the European Prison Rules, 11 January 2006, Rec(2006)2, https://www.refworld.org/docid/43f3134810.html, 22.06.2020.

13 Recommendation Rec(2003)23 of the Committee of Ministers to member states on the management by prison administrations of life sentence and other long-term prisoners, https://www.ochrance.cz/fileadmin/user upload/ochrana osob/Umluvy/vezenstvi/R 2003 23 m anagement of life sentence and long-term prisoners.pdf, 30.06.2020.

14 Council of Europe: Parliamentary Assembly, Resolution 428 (1970), Declaration on mass communication media and Human Rights, 23 January 1970, https://assembly.coe.int/nw/xml/XRef/Xref-XML2HTML-en.asp?fileid=15842\&lang=en, 22.06.2020.
} 


\section{Zbornik IKSI, 2-3/2O2O - A. Batrićević, I. Stepanović \\ „Video nadzor, bezbednost i pravo na privatnost u zatvorima”, (str. 27-44)}

i 2) zaštitu doma, porodičnog života, psihičkog i moralnog integriteta, kao i časti i ugleda (Paunović, Krivokapić, Krstić, 2013: 180).

Konvencija o zaštiti lica u odnosu na automatsku obradu ličnih podataka ima za cilj da se svim fizičkim licima na teritorijama strana ugovornica osigura poštovanje osnovnih prava i sloboda, a posebno prava na privatnost i to u kontekstu obrade ličnih podataka (član 1.). Konvencija ličnim podacima smatra sve informacije u vezi sa identifikovanim fizičkim licem ili licem koje se može identifikovati (član 2. tačka a). Iako Konvencija ne govori izričito o video nadzoru, iz navedene definicije proizlazi da nema prepreka da se njene odredbe primenjuju i na podatke o fizičkim licima prikupljenim na taj način. Odredbe Konvencije odnose se na takozvanu automatsku obradu podataka, a ona obuhvata sledeće operacije koje se delimično ili u potpunosti obavljaju automatski: unošenje podataka, obrada tih podataka pomoću logičkih i/ili aritmetičkih operacija, unošenje izmena, njihovo brisanje, pronalaženje ili difuziju (član 2. tačka c). Konvencija o zaštiti lica u odnosu na automatsku obradu ličnih podataka primenjuje se na zbirke i automatske obrade ličnih podataka u javnom i privatnom sektoru (ćlan 3.), a svaka strana ugovornica obavezna je da preduzme, u okviru svog nacionalnog zakonodavstva, neophodne mere kako bi se obezbedila primena Konvencije u praksi i to najkasnije u trenutku stupanja na snagu za tu stranu ugovornicu (član 4.).

Konvencija obavezuje države ugovornice da preduzimaju odgovarajuće bezbednosne mere sa ciljem zaštite ličnih podataka koji su pohranjeni u automatizovanim zbirkama od slučajnog ili neodobrenog uništenja ili od slučajnog gubitka, ali i od neodobrenog korišćenja, menjanja ili difuzije (član 7.). Osim toga, Konvencija u članu 8. propisuje i dodatne mere usmerene na zaštitu subjekata podataka. U pogledu pravila postavljenih Konvencijom, a koja se odnose na kvalitet podataka (član 5.), posebne kategorije podataka (član 6.) i dodatne mere zaštite subjekata podataka (član 8.) ne mogu se odobriti izuzeci niti ograničenja, osim u slučajevima predviđenim njenim članom 9. Naime, stavom 2. člana 9. Konvencije propisano je da se u državi ugovornici može odstupiti od navedenih odredbi samo ukoliko je takvo odstupanje predviđeno zakonom te države ugovornice i kada takvo odstupanje predstavlja neophodnu meru u jednom demokratskom društvu i to: 1) radi zaštite bezbednosti države, javne bezbednosti, monetarnih interesa države ili radi suzbijanja krivičnih dela; 2) radi zaštite subjekta podataka i prava i sloboda drugih, što je posebno bitno imati u vidu upravo u kontekstu podataka o ličnosti koji su pribavljeni video nadzorom u ustanovama za izvršenje krivičnih sankcija.

Evropska zatvorska pravila (u daljem tekstu: EZP) uspostavljaju niz pravila i načela od značaja za zaštitu ljudskih prava lica lišenih slobode, uključujući i pravo na privatnost. Međutim, odredbe EZP ne spominju eksplicitno problematiku video nadzora u zatvorima. Uprkos tome, ne postoje prepreke da se odredbe ovog dokumenta koje se odnose na privatnost primenjuju upravo u kontekstu zaštite prava osuđenika na privatnost $\mathrm{u}$ kontekstu vršenja video nadzora u svrhu očuvanja bezbednosti u zatvorima. EZP kao neke od osnovnih principa ističu da se prema svim licima lišenim slobode mora postupati uz poštovanje njihovih ljudskih prava, kao i da ta lica zadržavaju sva prava koja im nisu zakonito oduzeta odgovarajućom odlukom nadležnih organa (član 1. i 2.). Osim toga, propisano je da ograničenja za 


\section{Zbornik IKSI, 2-3/2O2O - A. Batrićević, I. Stepanović \\ „Video nadzor, bezbednost i pravo na privatnost u zatvorima”, (str. 27-44)}

lica lišena slobode treba da budu minimalna neophodna, te da moraju biti srazmerna legitimnom cilju zbog kojeg su im nametnuta (član 3).

Određena pravila od značaja za privatnost sadržana su i u delu EZP-a koji se odnosi na regulisanje uslova za zatvaranje. Tako je članom 18.1. propisano da uslovi smeštaja zatvorenika, a naročito prostorije za spavanje moraju biti takvi da ne ugrožavaju ljudsko dostojanstvo, kao i da, koliko god je to moguće, uvažavaju privatnost. Privatnost se uzima u obzir i u kontekstu pristupa sanitarnim prostorijama, te je tako članom 19.3. predviđeno da zatvorenici moraju imati pristup sanitarnim prostorijama, koje su higijenski ispravne i koje poštuju njihovu privatnost. Pravo zatvorenika na privatnost zajemčeno je odredbama EZP-a i u kontekstu garantovanja njihovog prava na konsultacije i drugu vrstu komunikacije, uključujući i prepisku između zatvorenika i njegovog pravnog savetnika, koje, prema članu 23.4. EZP-a mora biti poverljiva. Međutim, već je narednom odredbom (član 23.5.) predviđena mogućnost da sudski organ u izuzetnim okolnostima odobri ograničenje poverljivosti ovog oblika komunikacije, kako bi se sprečilo teže krivično delo ili teže narušavanje sigurnosti i bezbednosti zatvora.

Privatnost se uzima u obzir i u pravilima koja se odnose na komunikaciju zatvorenika sa "spoljnim svetom" te je tako propisano da oni imaju pravo da komuniciraju bez ograničenja, pismima, telefonom ili na drugi način, sa svojim porodicama, drugim licima i predstavnicima spoljašnjih organizacija i da primaju njihove posete (član 24. 1.). Ipak, postoji mogućnost da komunikacija i posete podležu ograničenjima i nadzoru ako to nalažu zahtevi nastavka krivične istrage, održavanja reda, sigurnosti i bezbednosti, sprečavanja krivičnih dela i zaštita žrtava, s tim što je naglašeno da takva ograničenja, uključujući konkretna ograničenja koja naloži sudski organ, moraju omogućavati minimalni nivo kontakta (član 24.2.). Osim toga, ostavljen je prostor da se nacionalnim zakonodavstvima odrede domaći i međunarodni organi i funkcioneri sa kojima zatvorenici imaju pravo da komuniciraju bez ograničenja (član 24. 3.).

I odredbe koje se odnose na održavanje reda u zatvoru naglašavaju da se tom prilikom moraju imati u vidu kako potrebe bezbednosti, sigurnosti i discipline, tako i potreba da se zatvorenicima omoguće životni uslovi koji podrazumevaju poštovanje ljudskog dostojanstva (član 49.). U skladu sa tim, EZP propisuju da se bezbednost osigurava fizičkim preprekama i drugim tehničkim sredstvima, a dopunjuje dinamičkom bezbednošću koju sprovodi osoblje spremno da reaguje i koje poznaje zatvorenike pod svojom kontrolom (član 51,2.), te da mere bezbednosti koje se primenjuju na pojedine zatvorenike moraju biti na nivou minimuma koji je neophodan da se obezbedi njihovo čuvanje (član 51.1.). Iako se među merama bezbednosti ne govori izričito o video nadzoru, on bi se mogao svrstati u "druga tehnička sredstva", te nema prepreke da se ova pravila primene upravo i na njega.

Direktiva o o zaštiti podataka o ličnosti u odnosu na policïske vlasti i u krivičnom postupku (Policijska direktiva EU) usvojena je 2016. godine, a primenjuje se od 25. maja 2018. godine (Pejić, 2019: 3). Policijska direktiva EU utvrđuje pravila relevantna za zaštitu pojedinaca u vezi sa obradom podataka o ličnosti od strane nadležnih organa u specifičnom kontekstu - u svrhu sprečavanja, istrage, otkrivanja 


\author{
Zbornik IKSI, 2-3/2O2O - A. Batrićević, I. Stepanović \\ „Video nadzor, bezbednost i pravo na privatnost u zatvorima”, (str. 27-44)
}

ili krivičnog gonjenja učinilaca krivičnih dela ili izvršenja krivičnih sankcija, uključujući zaštitu od pretnji javnoj bezbednosti i njihovo sprečavanje (član 1. stav 1.). Policijska direktiva obavezuje države članice EU da štite osnovna prava i slobode pojedinaca, a posebno pravo na zaštitu podataka o ličnosti, kao i da osiguraju da se razmena podataka o ličnosti između nadležnih organa unutar EU ne ograniči niti zabrani iz razloga povezanih sa zaštitom pojedinaca u vezi sa obradom ličnih podataka, onda kada se takva razmena zahteva u skladu sa pravom EU ili pravom države članice (član 1. stav 2.). Standardi postavljeni ovom direktivom predstavljaju minimalne standarde zaštite podataka o ličnosti u tom kontekstu, a države članice su slobodne da svojim nacionalnim zakonodavstvima predvide i snažnije mere zaštite (član 1. stav 3.).

Policijska direktiva EU se primenjuje na obradu podataka o ličnosti u prethodno pomenute svrhe (član 2. stav 1.) i to na obradu ličnih podataka koja se u celosti ili delimično obavlja automatizovano, ali i na neautomatizovanu obradu podataka koji čine ili su namenjeni da budu deo sistema čuvanja tih podataka (član 2. stav 2.). Policijska direktiva EU se ne primenjuje u Srbiji, ali je poznavanje njenih odredbi od strane relevantnih domaćih subjekata važno kako zbog nastojanja da se nacionalno zakonodavstvo naše zemlje u potpunosti uskladi sa acquis-om, tako i zbog činjenice da domaći organi sprovođenja zakona moraju da garantuju jednak stepen zaštite podataka o ličnosti kao i organi EU, kako bi već u ovom trenutku mogli nesmetano da ih razmenjuju sa njima za potrebe suzbijanja prekograničnog kriminaliteta (Pejić, 2019: 4).

Policijska direktiva EU definiše pojam "podataka o ličnosti" tako da obuhvata sve podatke koji se odnose na pojedinca čiji je identitet utvrđen ili se može utvrditi, odnosno koji se može identifikovati posredno ili neposredno, posebno uz pomoć idetifikatora kao što su: ime, matični broj, podaci o lokaciji mrežni idetifikator ili uz pomoć jednog ili više faktora koji su svojstveni za fizički, fiziološki, genetski, mentalni, ekonomski, kulturni ili socijalni identitet tog pojedinca (član 3. stav 1. tačka 1.). U kontekstu zaštite prava u vezi sa podacima o ličnosti onih lica koja se nalaze na izdržavanju kazne zatvora poseban značaj ima definicija pojma "izrada profila" data u Direktivi (član 3. stav 1. tačka 4), a prema kojoj "izrada profila" označava svaki oblik automatizovane obrade podataka o ličnosti koji se sastoji od upotrebe podataka o ličnosti za ocenu određenih ličnih aspekata povezanih sa pojedincem, a posebno za analizu ili predviđanje aspekata u vezi sa: radnim učinkom, ekonomskim stanjem, zdravljem, ličnim sklonostima, interesima, pouzdanošću, ponašanjem, lokacijom ili kretanjem tog pojedinca.

Policijska direktiva EU definiše povredu podataka o ličnosti kao kršenje sigurnosti koje dovodi do slučajnog ili do nezakonitog uništenja, gubitka, izmene, neovlašćenog otkrivanja ili pristupa ličnim podacima koji su preneseni, sačuvani ili na drugi način obrađivani (član 3. stav 1. tačka 11.). Lice čiji su podaci o ličnosti predmet obrade ima niz prava zagarantovanih Policijskom direktivom EU, čije su sadržina, realizacija, ali i ograničenja uređeni u njenom 3. poglavlju. Tako, ukoliko su za to ispunjeni uslovi propisani ovom Direktivom, ispitanik ima pravo: 1) da bude informisan o obradi podataka o ličnosti, 2) da traži i ostvari pristup ličnim podacima koje obrađivač o njemu poseduje, 3) da traži i dobije ispravku i/ili dopunu podataka, 4) na brisanje 


\author{
Zbornik IKSI, 2-3/202O - A. Batrićević, I. Stepanović \\ „Video nadzor, bezbednost i pravo na privatnost u zatvorima”, (str. 27-44)
}

podataka čijom se obradom krše pravila Direktive ili podataka koje je rukovalac dužan da izbriše, kao i 5) pravo na ograničenje obrade u pojedinim situacijama.

Na kraju, treba istaći da se i Preporuka Komiteta ministara državama članicama o tretmanu od strane zatvorske administracije zatvorenika koji izdržavaju doživotne $i$ druge dugogodišnje kazne iz 20o3. godine ${ }^{15}$, takođe dotiče problematike video nadzora u ustanovama za izvršenje krivičnih sankcija, ističući da video nadzor u takvim ustanovama treba da se upotrebljava kao dodatno sredstvo koje spada u takozvane metode dinamičke sigurnosti i kojim se doprinosi razvoju pozitivnih odnosa između osuđenih lica sa jedne i zatvorskog osoblja sa druge strane.

\title{
ZAKLJUČAK
}

S obzirom na to da video materijal koji prikupljaju nadzorne kamere sadrži podatke o ličnosti, video nadzor potencijalno ugrožava pravo na privatnost, zbog čega je neophodno razmotriti mogućnosti stvaranja adekvatnog balansa između bezbednosti i privatnosti u ustanovama za izvršenje krivičnih sankcija. Koncept bezbednosti, koji se decenijama unazad stavlja u prvi plan u okviru jedne šire "ideologije bezbednosti", u zapadnim liberalnim društvima ima značajan uticaj na kreiranje javnih politika u oblasti izvršenja krivičnih sankcija, koje, kako neki autori ističu, mogu voditi ka "totalitarizmu" u demokratskim i slobodnim društvima (Drake, 2012: 109). Zbog toga je pitanje odnosa prema konceptu zaštite ljudskih prava i sloboda osuđenika, a posebno njihovog prava na privatnost, deo mnogo šireg problema razgraničavanja i pomirenja individualnih i kolektivnih interesa.

Uprkos određenim prednostima na planu očuvanja bezbednosti, koje, međutim, još uvek nisu u dovoljnoj meri empirijski potvrđene, primena video nadzora u osobenim zatvorenim sistemima, u kakve spadaju upravo ustanove za izvršenje krivičnih sankcija, može proizvesti i brojne negativne posledice, među kojima se izdvajaju: pojava psiholoških problema usled pojačane kontrole, smanjenje interakcije između zatvorenika i zatvorskog osoblja, pojačanje osećaja izolovanosti, otuđenja i ugrožene bezbednosti (Kovačević-Lepojević, Žunić-Pavlović, 2012: 337). Video nadzor koji omogućava veću kontrolu i intenzivniju zaštitu bezbednosti doprinosi ograničavanju prava i sloboda osuđenika pa je zbog toga veoma važno ovu oblast detaljno pravno regulisati, ali i obezbediti doslednu primenu postojećih međunarodnih i nacionalnih pravnih izvora u praksi, kako bi se smanjile mogućnosti zloupotrebe i osiguralo poštovanje prava na privatnost, kao jednog od osnovnih ljudskih prava.

U Republici Srbiji video nadzor nije regulisan posebnim zakonom ili propisima, što otežava zaštitu prava na privatnost ne samo u ustanovama za izvršenje krivičnih sankcija (gde se o načinu primene ovih tehnologija odlučuje na nivou

\footnotetext{
15 Recommendation Rec(2003)23 of the Committee of Ministers to member states on the management by prison administrations of life sentence and other long-term prisoners, https://www.ochrance.cz/fileadmin/user upload/ochrana osob/Umluvy/vezenstvi/R $2003 \quad 23 \mathrm{~m}$ anagement of life sentence and long-term prisoners.pdf, 30.06.2020.
} 


\section{Zbornik IKSI, 2-3/2O2O - A. Batrićević, I. Stepanović \\ „Video nadzor, bezbednost i pravo na privatnost u zatvorima”, (str. 27-44)}

pojedinačnih ustanova), već i u svim drugim ustanovama, kao i u svim javnim i privatnim prostorima. Takođe treba istaći i da Republika Srbija nije formalno obevezna da poštuje odredbe Policijske direktive EU, ali da obaveze proistekle iz Evropskih integracija upravo nalažu detaljno upoznavanje relevantnih subjekata sa njenim odredbama, kao i njihovu doslednu i potpunu primenu u praksi.

Postojeća situacija u oblasti pravnog regulisanja video nadzora u ustanovama za izvršenje krivičnih sankcija u kontekstu poštovanja prava osuđenih lica na privatnost ukazuje na neophodnost preduzimanja nekoliko koraka, kako na međunarodnom, tako i na nacionalnom planu. Pre svega, potrebno je formulisati jednu opšteprihvaćenu definiciju prava na privatnost, kao i posebnu definiciju prava na privatnost osuđenih lica koja bi bila prilagođena osobenostima uslova života $\mathrm{u}$ zatvorima. Zatim, potrebno je preciznije odrediti kriterijume za poštovanje privatnosti "u skladu sa mogućnostima", budući da se oni mogu značajno razlikovati od jednog sistema izvršenja krivičnih sankcija do drugog, što otvara veoma širok prostor za nejasnoće, nedoslednosti i zloupotrebe. Konačno, imajući u vidu osobenosti, ali i sve veću rasprostranjenost video nadzora, potrebno je detaljnije regulisati tu oblast, kako na međunarodnom tako i na nacionalnom nivou. To se može sprovesti bilo kroz unošenje novih odredbi u postojeće pravne izvore, bilo usvajanjem novih zakonskih ili podzakonskih akata posvećenih isključivo propisivanju: načela, uslova sprovođenja, i ograničenja video nadzora, kako uopšte tako i u zatvorima, sa posebnim akcentom na očuvanju ljudskog dostojanstva i prava na privatnost. Osim preventivnih mehanizama, potrebno je pomenutim odredbama propisati i adekvatne sankcije za nepostupanje u skladu sa osnovnim principima sprovođenja video nadzora na način kojim se osigurava poštovanje ljudskog dostojanstva, a pre svega prava na privatnost.

\section{LITERATURA}

(1) Allard, T., Wortley, R., \& Stewart, A. (2006) The purposes of CCTV in prison.

Security Journal, 19(1), 58-70. https://doi.org/10.1057/Palgrave.sj.8350009

(2) Allard, T. J., Wortley, R. K., \& Stewart, A. L. (2008). The effect of CCTV on prisoner misbehavior. The Prison Journal, 88(3), 404-422.

https://doi.org/10.1177/0032885508322492

(3) Batrićević, A. (2011). Zaštitnik građana i poštovanje prava zatvorenika u Republici Srbiji. Branič, 124(1-2), 135-156.

(4) Batrićević, A. \& Ilijić, Lj. (2014). Health Care of Prisoners as A Crime Prevention Factor - General Standards and Conditions in Serbia. In Milašinović, S., Simović, D., Simeunović Patić, B. (Eds.), Thematic Conference Proceedings of International Significance, Vol 1, International Scientific Conference „Archibald Reiss Days“, pp. 441-450, Belgrade: Academy of Criminalistics and Police Science.

(5) Batrićević, A., Želeskov Đorić, J., Petrović, B. \& Knežić, B. (2020). Through Offenders' Eyes: A Pilot Study on Experiencing Supervision in Serbian Criminal Justice System. Teme, 44(2), 587-605. https://doi.org/10.22190/TEME180913041B

(6) Bauman, Z. (2010). Privacy, Secrecy, Intimacy, Human Bonds, Utopia and Other Collateral Casualties of Liquid Modernity. In H. Blatterer, P. Johnson, M.R. Markus 


\author{
Zbornik IKSI, 2-3/2O2O - A. Batrićević, I. Stepanović \\ „Video nadzor, bezbednost i pravo na privatnost u zatvorima”, (str. 27-44)
}

(Eds.), Modern Privacy: Shifting Boundaries, New Forms (pp. 7-22). Palgrave Macmillan, London. https://doi.org/10.1057/9780230290679_2

(7) Bauman, Z. \& Lyon, D. (2013). Liquid Surveillance. Cambridge: Polity Press. https://doi.org/10.1111/j.1749-5687.2010.00109.x

(8) Bentham, J. (1995). The Panopticon Writings. London and New York: Verso.

(9) Boston, J. (2006). Excessive Force in the New York City Jails: Litigation and its Lessons. Washington University Journal of Law and Policy, 22(1-13), 155-173. https://openscholarship.wustl.edu/law_journal_law_policy/vol22/iss1/13

(10) Brunon-Ernst, A. \& Tusseau, G. (2012). The Panopticon as a Contemporary Icon. In A. Brunnon-Ernst (Ed.) Beyond Foucault: New Perspectives on Bentham's Panopticon. Farnham: Ashgate.

(11) Council of Europe: Committee of Ministers, Recommendation Rec(2006)2 of the Committee of Ministers to Member States on the European Prison Rules, 11 January 2006, Rec(2006)2, dostupno na: https://www.refworld.org/docid/43f3134810.html, stranici pristupljeno 22.06.2020.

(12) Directive (EU) 2016/680 of the European Parliament and of the Council of 27 April 2016 on the protection of natural persons with regard to the processing of personal data by competent authorities for the purposes of the prevention, investigation, detection or prosecution of criminal offences or the execution of criminal penalties, and on the free movement of such data, and repealing Council Framework Decision 2008/977/JHA, dostupno na: https://eur-lex.europa.eu/legalcontent/EN/TXT/PDF/?uri=CELEX:32016Lo680\&from=EN, stranici pristupljeno 24.06.2020.

(13) Dimovski, D. \& Kostić, M. (2015). Penološki pristup prevelikom broju osuđenih lica u penitencijarnom sistemu Republike Srbije. NBP Žurnal za kriminalistiku i pravo, $2 O(2), 167-178$.

(14) Džunić, B. \& Dragojlović, J. (2019). Pravni okvir održavanja bezbednosti u zatvorima u Srbiji i praktični izazovi. Vojno delo, 71(4), 197-208. https://doi.org/10.5937/vojdelo1904197D

(15) European Data Protection Board. (2019). Guidelines 3/2019 on processing of personal data through video devices, dostupno na: https://edpb.europa.eu/sites/edpb/files/files/file1/edpb_guidelines_201903_vide o_devices.pdf, stranici pristupljeno: 03.072020.

(16) European Data Protection Supervisor, Video-surveillance, dostupno na: https://edps.europa.eu/data-protection/data-protection/reference-library/videosurveillance_en, stranici pristupljeno 03.07.2020.

(17) Fairweather, L. \& McConville, S. (2013). Prison Architecture. London: Routledge.

(18) Fajf, N. \& Banister, Dž. (2002). Oči uprte u ulicu, CCTV nadzor i grad. U Fajf, N. (ur.), Prizori ulice. Beograd: Clio, 351-368.

(19) Foucault, M. (2020). Discipline and Punish: The Birth of Prison. London: Penguin Books.

(20) Gibbons, J. \& De B. Katzenbach, N. (2006). Confronting Confinement - A Report of the Commission on Safety and Abuse in America's Prisons. New York: Vera Institute of Justice.

(21) Glass, A. (2010). Privacy and Law. In H. Blatterer, P. Johnson \& M. R. Markus (Eds.), Modern Privacy: Shifting Boundaries, New Forms. London: Palgrave MacMillan.

(22) Grujić, Z. \& Milić, I. (2016). Prison Overcrowding - Mitigating the Consequences, Archibald Reiss Days, Tematski zbornik radova (str. 268-296). Beograd: Kriminalističko-policijska akademija.

(23) Henriquez, M. (2019). On the Inside and Out: How Video Surveillance is Essential to Prison Security, 23.09.2019., dostupno na: 


\author{
Zbornik IKSI, 2-3/2O2O - A. Batrićević, I. Stepanović \\ „Video nadzor, bezbednost i pravo na privatnost u zatvorima”, (str. 27-44)
}

https://www.securitymagazine.com/articles/90974-on-the-inside-and-out-howvideo-surveillance-is-essential-to-prison-security, stranici pristupljeno 07.07.2020.

(24) Ingles v. Toro, 438 F. Supp. 2 d 203 (S.D.N.Y.) (2006), dostupno na: https://www.clearinghouse.net/detail.php?id=5483, stranici pristupljeno 02.07.2020.

(25) Jewkes, Y., Crewe, B. \& Bennett, J. (2016). Handbook on Prisons. London: Routledge.

(26) Joković, J. (2018). Socijalna kontrola u zavodskim uslovima. Putokazi, 6(2), 305-318.

(27) Lugo, M. A. \& Wooldredge, J. (2017). Overcrowding in Prisons. In K. R. Kerley (Ed.), The Encyclopedia of Corrections. Wiley-Blackwell.

(28) Kovačević-Lepojević, M. \& Žunić-Pavlović, V. (2012). Primena video nadzora u kontroli kriminala. Specijalna edukacija i rehabilitacija, 11(2), 325-345.

(29) Krivokapić, D., Adamović, J., Tasić, D., Petrovski, A., Kalezić, P. \& Krivokapić, Đ. (2019) Vodič kroz Zakon o zaštiti podataka o ličnosti i GDPR - tumačenje novog pravnog okvira. Beograd: Misija OEBS-a u Srbiji i Share fondacija, dostupno na: https://www.sharefoundation.info/Documents/vodic_zzpl_gdpr_share_2019.pdf, stranici pristupljeno 03.07.2020.

(30) MacDonald, M. (2018). Overcrowding and its impact on prison conditions and health. International Journal of Prisoner Health, 14(2), 65-68. https://doi.org/10.1108/IJPH-04-2018-0014

(31) Mai, J. E. (2020). Three models of privacy: New perspectives on informational privacy. Nordicom review, 37(s1), 171-175. https://doi.org/10.1515/nor-2016-0031

(32) Maple, C. (2017). Security and Privacy in the Internet of Things. Journal of Cyber Policy, 2(2), 155-184. https://doi.org/10.1080/23738871.2017.1366536

(33) Marković, Ž. (2010) Postupanje prema licima lišenim slobode. Beograd: Beogradski centar za ljudska prava.

(34) Marshall, D. \& Thomas, T. (2017). Punishment and Privacy. Privacy and Criminal Justice. Palgrave Macmillan, Cham.

(35) Moore, A. D. (2011). Privacy, Security and Government Surveillance: Wikileaks and the New Accountability. Public Affairs Quarterly, 25(2), 141-156.

(36) Morris, R. \& Worrall, J. (2010) Prison Architecture and Inmate Misconduct: A Multilevel Assessment. Crime and Delinquency, 6o(7), 1083-1109. https://doi.org/10.1177/0011128710386204

(37) Paunović, M., Krivokapić, B. \& Krstić, I. (2013). Međunarodna ljudska prava. Beograd: Pravni fakultet Univerziteta u Beogradu.

(38) Pavone, V., Santiago Gomez, E. \& Jaquet-Chifelle, D.O. (2016). A Systemic Approach to Security: Between the Tradeoff Between Security and Liberty. Democracy and Security, 12(4), 225-246. https://doi.org/10.1080/17419166.2016.1217776

(39) Pejić, J. (2019) Šta je policijska direktiva Evropske unije? Kako organi sprovođenja zakona (treba da) štite lične podatke. Beograd: Beogradski centar za bezbednosnu politiku.

(40) Recommendation Rec(2003)23 of the Committee of Ministers to member states on the management by prison administrations of life sentence and other long-term prisoners, dostupno na: https://www.ochrance.cz/fileadmin/user_upload/ochrana_osob/Umluvy/vezenstv i/R_2003_23_management_of_life_sentence_and_long-term_prisoners.pdf, stranici pristupljeno 30.06.2020.

(41) Regulation (EU) 2016/679 of the European Parliament and of the Council of 27 April 2016 on the protection of natural persons with regard to the processing of personal data and on the free movement of such data, and repealing Directive 95/46/EC (General Data Protection Regulation), OJ L 119, 4.5.2016, str. 1-88, 


\author{
Zbormik IKSI, 2-3/202O - A. Batrićević, I. Stepanović \\ „Video nadzor, bezbednost i pravo na privatnost u zatvorima”, (str. 27-44)
}

dostupno na: http://data.europa.eu/eli/reg/2016/679/oj, stranici pristupljeno 22.06.2020.

(42) Sajfert, J. \& Quintel, T. (2019). Data Protection Directive (EU) 2016/680 for Police and Criminal Justice Authorities. In: Cole, M. \& Boehm, F. (Eds.) GDPR Commentary (forthcoming, Edward Elgar Publishing 2019), dostupno na: https://papers.ssrn.com/sol3/Delivery.cfm/SSRN_ID3285873_code2727491.pdf?a bstractid $=3285873 \&$ mirid $=1 \&$ type $=2$, stranici pristupljeno 26.06.2020.

(43) Snouden, E. (2020). Trajno zabeleženo (drugo izdanje). Beograd: Vulkan izdavaštvo.

(44) Stepanović, I. (2020). Zivot na internetu: pravo na privatnost $i$ online komunikacija. Beograd: Institut za kriminološka i sociološka istraživanja.

(45) Stepanović, I. (2019). Privacy and Digital Literacy: Who is Responsible for the Protection of Personal Data in Serbia? Zbornik Instituta za kriminološka i sociološka istraživanja, 38(3), 45-56.

(46) Stepanović, I. (2018). Redefining Privacy in Serbia: A Challenge for Public Policy. Zbornik Instituta za kriminološka i sociološka istraživanja, 37(1), 103-115.

(47) Stepanović, I. (2015). Control of the Private Life and Crime Prevention in Serbia. Zbornik Instituta za kriminološka i sociološka istraživanja, 36(1), 77-93.

(48) Stepanović, I. (2014). Modern Technology and Challenges to Protection of the Right to Privacy, Annals FLB - Belgrade Law Review, 62(3), 167-178.

(49) Strategija za smanjenje preopterećenosti smeštajnih kapaciteta u zavodima za izvršenje krivičnih sankcija u Republici Srbiji do 2020. godine, Službeni glasnik RS, br. 43/2017.

(50) UN General Assembly, Universal Declaration of Human Rights, 10 December 1948, 217 A (III), dostupno na: https://www.refworld.org/docid/3ae6b3712c.html, stranici pristupljeno 22.06.2020.

(51) Waldron, J. (2010). Torture, Terror and Trade-Offs. Oxford: Oxford University Press.

(52) Yu, S. (2016). Big Privacy: Challenges and Opportunities of Privacy Study in the Age of Big Data. IEEE ACCESS The Multidisciplinary Open Access Journal, 4, 27512763. https://doi.org/10.1109/ACCESS.2016.2577036

(53) Zakon o potvrđivanju Konvencije o zaštiti lica u odnosu na automatsku obradu ličnih podataka, Službeni list SRJ - Međunarodni ugovori, br. 1/1992, Službeni list SCG -Međunarodni ugovori, br. 11/2005 i Službeni glasnik RS - Međunarodni ugovori, br. 98/2008 i 12/2010.

(54) Zakon o potvrđivanju Protokola o izmenama i dopunama Konvencije o zaštiti lica u odnosu na automatsku obradu ličnih podataka, Službeni glasnik RS - Međunarodni ugovori, br. 4/2020.

(55) Zakon o ratifikaciji Međunarodnog pakta o građanskim i političkim pravima, Službeni list SFRJ, br. 7/1971-73.

(56) Zakon o ratifikaciji Evropske konvencije za zaštitu ljudskih prava i osnovnih sloboda, Službeni list SCG - Međunarodni ugovori, br. 9/2003, 5/2005 i 7/2005 i Službeni glasnik RS - Međunarodni ugovori, br. 12/2010 i 10/2015.

(57) Zakon o zaštiti podataka o ličnosti, Službeni glasnik RS, br. 87/2018.

(58) Želeskov Đorić, J. \& Batrićević, A. (2014). Offender Supervision in Europe General Trends and Serbian Experience. Nauka Bezbednost Policija, 19(2), 75-94.

(59) Želeskov Đorić, J. \& Batrićević, A. (2013). Offender Supervsion in Europe Country Report for Serbia - 2013, COST Action IS 1106: Offender Supervision in Europe, dostupno na: http://www.offendersupervision.eu/wpcontent/uploads/2013/10/Offender-supervision-in-Serbia.pdf, stranici pristupljeno 07.09.2020. 


\section{VIDEO SURVEILLANCE, SECURITY AND THE RIGHT TO PRIVACY IN PRISONS}

The ever-changing technology landscape keeps posing new challenges to privacy protection as smart devices and surveillance mechanisms have the capacity to create large databases of personal information. From public places and private homes to penitentiaries, video surveillance may jeopardize the right to privacy, and it needs to be thoroughly regulated in order to create and maintain a balance between privacy and security. However, video surveillance is not regulated by a specific law in Serbia, which opens a series of disputable issues, especially in the context of prisons where the decision on the actual manner in which these technologies are applied is made within a particular penitentiary institution. The aim of this paper is to analyse how the right to privacy of prisoners has been conceptualised in international law, to highlight the question of the necessity, advantages and disadvantages of video surveillance in prisons, as well as to raise awareness about the problems that may emerge in this under-regulated field.

KEYWORDS: video surveillance / the right to privacy / security / prisons / human rights 